\title{
The Yeast Signal Sequence Trap Identifies Secreted Proteins of the Hemibiotrophic Corn Pathogen Colletotrichum graminicola
}

\author{
Jorrit-Jan Krijger, ${ }^{1}$ Ralf Horbach, ${ }^{1}$ Michael Behr, ${ }^{1}$ Patrick Schweizer, ${ }^{2}$ Holger B. Deising, ${ }^{1}$ and \\ Stefan G. R. Wirsel ${ }^{1}$ \\ ${ }^{1}$ Naturwissenschaftliche Fakultät III, Institut für Agrar- und Ernährungswissenschaften, Martin-Luther-Universität Halle- \\ Wittenberg, Ludwig-Wucherer-Str. 2, D-06099 Halle (Saale), Germany; ${ }^{2}$ Leibniz-Institut für Pflanzengenetik und \\ Kulturpflanzenforschung (IPK), Corrensstr. 3, D-06466 Gatersleben, Germany
}

Submitted 5 March 2008. Accepted 9 June 2008.

\begin{abstract}
The hemibiotroph Colletotrichum graminicola is the causal agent of stem rot and leaf anthracnose on Zea mays. Following penetration of epidermal cells, the fungus enters a short biotrophic phase, followed by a destructive necrotrophic phase of pathogenesis. During both phases, secreted fungal proteins are supposed to determine progress and success of the infection. To identify genes encoding such proteins, we constructed a yeast signal sequence trap (YSST) cDNA-library from RNA extracted from mycelium grown in vitro on corn cell walls and leaf extract. Of the 103 identified unigenes, 50 showed significant similarities to genes with a reported function, 25 sequences were similar to genes without a known function, and 28 sequences showed no similarity to entries in the databases. Macroarray hybridization and quantitative reverse-transcriptase polymerase chain reaction confirmed that most genes identified by the YSST screen are expressed in planta. Other than some genes that were constantly expressed, a larger set showed peaks of transcript abundances at specific phases of pathogenesis. Another set exhibited biphasic expression with peaks at the biotrophic and necrotrophic phase. Transcript analyses of in vitro-grown cultures revealed that several of the genes identified by the YSST screen were induced by the addition of corn leaf components, indicating that host-derived factors may have mimicked the host milieu.
\end{abstract}

Additional keywords: biotrophy, cell-wall-degrading enzymes, effector proteins, necrotrophy, peptidases.

Reverse genetic approaches have been proven to represent powerful tools to study the interaction between plants and their fungal pathogens at the molecular level. Hemibiotrophic fungi such as various Colletotrichum spp. are excellent model systems, because they combine features characteristic of two groups of pathogens with divergent modes of nutrition and lifestyles (i.e., obligate biotrophs and necrotrophs). For example,

Corresponding author: S. G. R. Wirsel; Telephone: +49 (0)345 5522672; Fax: +49(0)345 5527120; stefan.wirsel@landw.uni-halle.de

Sequence data generated during this work have been annotated at the EMBL database under the accession numbers AM944392 to AM944496.

* The $\boldsymbol{e}$-Xtra logo stands for "electronic extra" and indicates that four supplemental tables are published online. whereas the first infection structures formed in the host cell by the maize anthracnose and stem rot fungus Colletotrichum graminicola (teleomorph Glomerella graminicola) (i.e., infection vesicles and primary hyphae) are biotrophic, subsequently formed secondary hyphae are highly destructive and exhibit a necrotrophic lifestyle (Bergstrom and Nicholson 1999). In order to establish a biotrophic interaction, obligate biotrophs and hemibiotrophs seem to use similar strategies, because both suppress defense responses and reprogram the metabolism of their host (Münch et al. 2008). During the infection process, plant-pathogenic Eumycota and Oomycota secrete proteins that are directed to several subcellular locations (i.e., the cell wall of the host or the pathogen, the apoplast, or the cytoplasm) and diverse organelles of the host). Although it is generally assumed that some of these secreted proteins play important roles in the establishment of compatible interactions, there are only a few examples that have proven this (Catanzariti et al. 2007; Jones and Dangl 2006). Recent surveys of the sequenced genomes of Magnaporthe grisea (Dean et al. 2005), Phytophthora sojae, $P$. ramorum (Tyler et al. 2006), and Ustilago maydis (Kämper et al. 2006) have shown that the entirety of the secreted proteins of these pathogens, the so-called secretome, comprises approximately 7 to $10 \%$ of their predicted proteomes. For $U$. maydis, it has been revealed that a part of the secretome is organized in gene clusters, and 5 of 12 gene clusters analyzed by reverse genetics were found to be important for fungal virulence (Kämper et al. 2006).

Because protocols for gene inactivation and overexpression are available in Colletotrichum spp., not only the necrotrophic but also the biotrophic lifestyle can be studied in the same genetic background at the molecular level. We used the hemibiotrophic ascomycete $C$. graminicola to investigate the secretome at different stages of the infection process, including prepenetration, biotrophic, and necrotrophic stages. The complete genome sequence of $C$. graminicola is not yet available; therefore, bioinformatic approaches cannot be employed to analyze the secretome of this pathogen. However, genetic methods have been developed to identify secreted proteins. One of these, the yeast signal sequence trap (YSST), uses a strain of Saccharomyces cerevisiae with a genomic deletion at the SUC2 locus (Klein et al. 1996). Thus, the SUC2-deficient yeast strain does not secrete invertase and, therefore, is unable to grow on sucrose as the sole carbon source. The second component of the YSST is a vector with a SUC2 gene lacking the signal sequence and the start codon. Only if a partial cDNA provides these sequence elements is the fusion protein translo- 
cated into the secretion pathway. In modified versions of the system, the truncated $S U C 2$ gene is driven by the constitutive promotor $A d h 2^{P}$ from $S$. cerevisiae that is directly followed by cloning sites and a Kex 2 protease splicing sequence. In the Golgi, the Kex 2 protease cleaves the fusion protein so that invertase is secreted in its native state. Thus, all transformants carrying a secretion signal should be able to grow on sucrose, regardless of the nature of the heterologous peptide. The YSST has been successfully applied to screen cDNA libraries generated from animals, plants, and microbes, including the broad bean rust Uromyces fabae and the Oomycete $P$. infestans, causing late blight of potato and tomato (Goo et al. 1999a,b; Hugot et al. 2004; Jacobs et al. 1997; Klein et al. 1996; Lee et al. 2006, 2001; Link and Voegele 2008; Monteoliva et al. 2002; Wang et al. 2001).

The large set of genes encoding secreted proteins presented here is the first from a hemibiotrophic ascomycete and the first to be extensively studied by macroarray hybridizations and quantitative reverse-transcriptase polymerase chain reaction (qRT-PCR) to determine regulation at the transcriptional level

Table 1. Yeast signal sequence trap clones with similarity to functionally known proteins ${ }^{\mathrm{a}}$

\begin{tabular}{|c|c|c|c|c|c|c|c|c|c|}
\hline Clone & Accession & $\begin{array}{l}\text { Insert } \\
\text { (bp) }\end{array}$ & $\begin{array}{l}\text { Peptide } \\
\text { (aa) }\end{array}$ & $\begin{array}{l}\text { SP3 } \\
\text { HMM }\end{array}$ & $\begin{array}{c}\text { TMHMM } \\
\text { helices }\end{array}$ & $\begin{array}{c}\text { blastp } \\
\text { E-value }\end{array}$ & Accession & Species & Putative function \\
\hline 112 & AM944395 & 572 & 147 & 0.999 & $\ldots$ & $3 e-44$ & XP_660941 & Aspergillus nidulans & Pectate lyase \\
\hline 148 & AM944397 & 656 & 135 & 0.999 & $\ldots$ & $3 e-42$ & EAA32292 & Neurospora crassa & $1,3-\beta$-Glucanosyltransferase \\
\hline 152 & AM944398 & 263 & 70 & 1.000 & $\cdots$ & $9 \mathrm{e}-11$ & EAQ90095 & Chaetomium globosum & $\begin{array}{l}\text { Rhamnogalacturan } \\
\text { acetylesterase }\end{array}$ \\
\hline 183 & AM944400 & 358 & 101 & 0.681 & $\ldots$ & $2 e-38$ & XP_387616 & Fusarium graminearum & Methyltransferase \\
\hline 236 & AM944405 & 757 & 250 & 1.000 & $\ldots$ & $7 e-59$ & EDK02137 & Magnaporthe grisea & GMC oxidoreductase \\
\hline 461 & AM944407 & 1455 & 452 & 0.991 & $\ldots$ & $3 e-63$ & XP_385839 & F. graminearum & Polysaccharide deacetylase \\
\hline 525 & AM944410 & 954 & 255 & 0.996 & $\ldots$ & $3 e-93$ & EAT77212 & Phytophthora nodorum & Endoglucanase \\
\hline 536 & AM944412 & 1160 & 315 & 0.992 & $\ldots$ & $2 \mathrm{e}-87$ & EAA33178 & $N$. crassa & Endoglucanase \\
\hline 541 & AM944413 & 961 & 298 & 0.999 & $\ldots$ & $1 \mathrm{e}-105$ & P23360 & Thermoascus aurantiacus & Endo-1,4- $\beta$-xylanase \\
\hline 550 & AM944417 & 1160 & 342 & 0.998 & $\ldots$ & $9 e-148$ & BAF62454 & Acremonium sp. & Subtilisin protease \\
\hline 735 & AM944420 & 248 & 61 & 0.999 & $\ldots$ & $2 \mathrm{e}-12$ & AAC41683 & M. grisea & Endo-1,4- $\beta$-xylanase \\
\hline 753 & AM944421 & 908 & 294 & 1.000 & $\ldots$ & 1e-97 & XP_391664 & F. graminearum & Endoglucanase \\
\hline 775 & AM944423 & 350 & 112 & 0.999 & $\ldots$ & $2 e-35$ & EAWW08572 & Aspergillus clavatus & Isoamyl alcohol oxidase \\
\hline 805 & AM944427 & 361 & 21 & 0.998 & $\ldots$ & $1 \mathrm{e}-03$ & EAQ87906 & Chaetomium globosum & $\beta$-Glucosidase \\
\hline 818 & AM944428 & 1200 & 316 & 1.000 & $\ldots$ & $1 \mathrm{e}-141$ & XP_389542 & F. graminearum & Exo- $\beta$-1,3-glucanase \\
\hline 867 & AM944438 & 347 & 82 & 0.996 & $\ldots$ & $4 e-19$ & XP_387071 & F. graminearum & Ser carboxypeptidase \\
\hline 891 & AM944441 & 350 & 45 & 1.000 & $\ldots$ & $2 e-04$ & XP_384016 & F. graminearum & Endoglucanase \\
\hline 908 & AM944444 & 257 & 80 & 0.999 & $\ldots$ & $6 e-16$ & EDJ97021 & M. grisea & Laccase \\
\hline 1027 & AM944451 & 766 & 245 & $0.787^{(\mathrm{SA})}$ & 5 & $2 e-97$ & EDN97496 & Sclerotinia sclerotiorum & $\beta$-1,3-D-glucan synthase \\
\hline 1042 & AM944455 & 520 & 66 & 1.000 & $\ldots$ & $8 \mathrm{e}-17$ & EAQ86156 & C. globosum & $\beta$-1,3-Glucanosyltransferase \\
\hline 1070 & AM944462 & 768 & 164 & 0.999 & $\ldots$ & $6 e-54$ & AAS45248 & Verticillium dahliae & $\begin{array}{l}\text { GPI-anchored glycanosyl } \\
\text { transferase }\end{array}$ \\
\hline 1088 & AM944466 & 559 & 170 & 0.997 & $\ldots$ & $4 e-46$ & AAR10769 & V. dahliae & Serine protease \\
\hline 1117 & AM944472 & 1,431 & 458 & 0.997 & $\ldots$ & $2 \mathrm{e}-161$ & XP_001219251 & C. globosum & Peptidase M28 \\
\hline 1146 & AM944477 & 1,211 & 400 & 1.000 & $\ldots$ & $6 e-166$ & BAB32575 & Colletotrichum lagenarium & Laccase \\
\hline 1149 & AM944478 & 384 & 111 & 0.982 & $\ldots$ & $8 e-39$ & EAA30457 & N. crassa & Polysaccharide deacetylase \\
\hline 1174 & AM944482 & 975 & 261 & 0.992 & $\ldots$ & $8 e-79$ & EAA29347 & $N$. crassa & Endoglucanase \\
\hline 1176 & AM944483 & 379 & 122 & 0.807 & $\ldots$ & $7 e-20$ & XP_385344 & F. graminearum & Quercetinase \\
\hline 1196 & AM944487 & 777 & 235 & 1.000 & $\ldots$ & $6 e-92$ & EDK00920 & M. grisea & $\alpha$-LK-arabinofuranosidase \\
\hline 1204 & AM944491 & 532 & 177 & 0.999 & $\ldots$ & $4 e-39$ & XP_001398268 & Aspergillus niger & Peptidase M28 \\
\hline 1206 & AM944492 & 1395 & 325 & 0.975 & $\ldots$ & $5 e-61$ & XP_001597818 & S. sclerotiorum & Endoglucanase \\
\hline 220 & AM944403 & 1138 & 240 & 0.001 & 1 & $8 \mathrm{e}-54$ & EDK05084 & M. grisea & RING-8 protein \\
\hline 221 & AM944404 & 501 & 162 & 0.918 & $\cdots$ & $7 e-60$ & AAX07715 & M. grisea & $\begin{array}{l}\text { Expressed mainly in } \\
\text { appressoria }\end{array}$ \\
\hline 252 & AM944406 & 271 & 74 & 0.675 & 2 & $5 e-30$ & XP_385177 & F. graminearum & Stress response \\
\hline 487 & AM944409 & 682 & 185 & 0.997 & $\ldots$ & $3 e-22$ & EAW12375 & Aspergillus clavatus & Extracellular serin-rich protein \\
\hline 526 & AM944411 & 1191 & 282 & 1.000 & $\ldots$ & $1 \mathrm{e}-03$ & EDK46315 & Lodderomyces elongisporus & Structural cell-wall protein \\
\hline 546 & AM944415 & 627 & 173 & 0.999 & $\ldots$ & $8 \mathrm{e}-09$ & XP_390301 & F. graminearum & Clock-controlled protein \\
\hline 782 & AM944424 & 607 & 180 & 0.120 & 1 & $1 e-36$ & EAQ89699 & Chaetomium globosum & Oligopeptide transporter \\
\hline 803 & AM944426 & 788 & 210 & 0.002 & 5 & $5 e-77$ & EAA34662 & N. crassa & Quinate transporter \\
\hline 838 & AM944432 & 377 & 82 & 1.000 & $\ldots$ & $7 e-19$ & XP_390301 & F. graminearum & Clock-controlled protein \\
\hline 860 & AM944436 & 463 & 141 & 0.999 & $\cdots$ & $9 e-21$ & AAA77681 & $\begin{array}{l}\text { Colletotrichum } \\
\text { gloeosporioides }\end{array}$ & $\begin{array}{l}\text { CAP22; appressorial cell-wall } \\
\text { protein }\end{array}$ \\
\hline 878 & AM944440 & 338 & 84 & 1.000 & $\ldots$ & $1 \mathrm{e}-19$ & XP_382007 & F. graminearum & Class II hydrophobin \\
\hline 990 & AM944447 & 1,030 & 257 & $0.136^{(\mathrm{SA})}$ & 5 & $1 e-105$ & EDN91030 & S. sclerotiorum & $\begin{array}{l}\text { Golgi GDP-mannose } \\
\text { transporter }\end{array}$ \\
\hline 1049 & AM944456 & 947 & 253 & 1.000 & $\ldots$ & $1 e-38$ & XP_384352 & F. graminearum & Allergen Asp F4-like \\
\hline 1059 & AM944459 & 1,130 & 333 & 1.000 & & $2 \mathrm{e}-18$ & XP_384060 & F. graminearum & Carbohydrate-binding \\
\hline 1091 & AM944467 & 265 & 81 & 0.999 & $\ldots$ & $4 e-24$ & EDK05992 & M. grisea & Cerato-platanin \\
\hline 1094 & AM944468 & 978 & 244 & 1.000 & $\ldots$ & $6 e-19$ & XP_390937 & F. graminearum & Related to lustrin A, structural \\
\hline 1096 & AM944469 & 780 & 206 & 0.999 & $\ldots$ & $8 \mathrm{e}-27$ & XP_001597705 & S. sclerotiorum & Extracellular matrix protein \\
\hline 1189 & AM944485 & 1,142 & 268 & 0.999 & $\ldots$ & $2 e-39$ & EAA29610 & N. crassa & Related to Rasp F7 allergen \\
\hline 1200 & AM944490 & 280 & 77 & 1.000 & $\cdots$ & $2 \mathrm{e}-03$ & EAW11256 & Aspergillus clavatus & $\begin{array}{l}\text { Antigenic cell-wall } \\
\text { galactomannoprotein }\end{array}$ \\
\hline 1209 & AM944494 & 1,013 & 308 & 0.014 & 7 & $2 e-136$ & XP_385528 & F. graminearum & MFS hexose transporter \\
\hline
\end{tabular}

${ }^{\text {a }}$ Peptide $=$ length of peptide (amino acids [aa]) encoded by the unigene; SP3 HMM = SignalP 3.0 hidden Markov model method, scores in bold = no predicted signal peptide; TMHMM = transmembrane helix prediction by hidden Markov model; $(\mathrm{SA})=$ predicted signal anchor. The upper part of the table shows putative enzymes and the lower part, beginning with clone 220, nonenzymes. For entries highlighted in gray, expression data are shown in Figures 2 and 3 . 
in the course of infection and during growth under various conditions in vitro. This work establishes a set of candidate genes that will be further characterized by reverse genetic approaches to identify putative effector proteins important for virulence.

\section{RESULTS}

\section{Construction and screening of a YSST library.}

A preculture of $C$. graminicola grown on glucose in liquid medium was starved in pure water and thereafter transferred to a minimal medium containing a cell-free soluble corn leaf extract and a preparation of corn leaf cell wall fragments. To identify secreted proteins which are only transiently produced, the cDNA library was created from pooled mRNAs prepared from mycelia harvested at different times after addition of leaf extracts and cell walls. A theoretical total of $1.5 \times 10^{6}$ yeast cells that were able to grow without leucine on glucose were plated on $\mathrm{SC} / \mathrm{leu}$ /sucrose. Of a total of $2.5 \times 10^{5}$ transformants obtained, 3,261 were subjected to a second selection cycle on $\mathrm{SC} / \mathrm{leu}^{-} /$sucrose/antimycin A. Colonies surviving the second selection were initially all sequenced. However, it turned out that some cDNAs were highly redundant. Therefore, primer pairs targeting seven of the redundant cDNAs were designed for multiplex PCR assays. Of these, five encoded putative homologs to Thermoascus aurantiacus endo-1,4- $\beta$-xylanase and Fusarium graminearum Asp F4-like allergen (clones 541 and 1049, Table 1), M. grisea putative proteins MGG03326 and MGG09844 (clones 1033 and 1031; Supplementary Table 1), and one without any homology (clone 606, Supplementary Table 2). The remaining two clones originated from 18S- and 28S-rRNA internal fragments and, thus, were false positives. Clones that did not yield a product in the multiplex PCR assay were sequenced. In total, 740 clones were sequenced during this work.

\section{Analysis and classification of YSST clones.}

The comparison of the sequences from all clones revealed 160 unigenes. Their translated amino acid sequences were subjected to analysis by SignalP 3.0 and transmembrane helix prediction by hidden Markov model (TMHMM), softwares trained to identify signal sequence peptides and transmembrane helices, respectively. Ninety-two of the unigene-encoded sequences had hidden Markov model (HMM) scores of higher than 0.5 in SignalP. One derived protein (no. 1137) had a SignalP score of 0.394 but was considered secreted for having a perfect score distribution and showing significant similarity to several closely related putative proteins of fungal origin that all had high SignalP scores for secretion signals or signal anchors. Five unigenes were predicted to encode one or several transmembrane helices but no signal peptide. Another three unigenes encoded peptides predicted to possess at least one transmembrane helix plus a signal peptide (no. 252 and 835) or a signal anchor, defined as a noncleaved signal peptide (no. 1027). In two cases, predictions remained unsettled. The same sequence was predicted to be a transmembrane helix and a signal peptide (no. 11) or a signal anchor (no. 1077). Of the remaining 57 unigenes, 21 encoded cytosolic proteins, 9 were wrong-frame fusions resulting in artificial signal peptides, and the remainder were sequences giving rise to fused peptides with SignalP values well below the threshold of 0.5 .

BlastP and BlastX searches revealed that none of the 103 unigenes obtained by YSST was previously reported from $C$. graminicola, indicating that our screen successfully retrieved a novel and significant fraction of the secretome of this fungus. Comparison of the protein sequences encoded by the unigenes to the currently annotated databases suggested that they could be divided into three classes (Fig. 1). In all, 50 sequences showed similarity to genes or proteins with a reported function, 25 sequences were similar to genes or proteins without a reported function, and 28 sequences showed no similarity to any entry in the databases. Of the 50 sequences with a putative function, 12 assignments (nos. 148, 487, 541, 550, 735, 775, $860,878,1070,1088,1146$, and 1198) were derived from the best database hit and the remaining from lower-ranking hits. In the latter case, the best match originated from an entry of a fungal genome project that had no annotated function. These 50 sequences were further subdivided into a group of 30 putative enzymes and a group of 20 nonenzymes (Table 1). Five proteins showed similarity to members of EC class 1 of oxidoreductases (i.e., a putative glucose-methanol-choline oxidoreductase [clone 236], a putative isoamylalcohol oxidase [clone 775], putative laccases [clones 908 and 1146], and a putative quercetinase [clone 1176]). Clones 148, 1042, and 1070 encoded glycanosyl transferases and clone 183 a methyl transferase, all belonging to EC class 2 of transferases. Most of the enzymes grouping within EC class 3 of hydrolases represented members of EC subclass 3.2 of glycosidases. These included glucanases (clones 525, 536, 753, 818, 891, 1174, and 1206), xylanases (clones 541 and 735), one $\beta$-glucosidase (clone $805)$, and an arabinofuranosidase (clone 1196). The EC subclass 3.4 , peptidases, contained five clones $(550,867,1088,1117$, and 1204). The remaining enzymes in EC class 3, a rhamnogalacturan acetylesterase (clone 152), and two polysaccharide deacetylases (clones 461 and 1149) fell into subclasses 3.1 and 3.5 of ester bond and nonpeptide $\mathrm{C}-\mathrm{N}$ bond hydrolases, respectively. Clone 112 encoded a pectate lyase belonging to EC class 4 of lyases. Finally, clone 1027 encoded an intramembrane $\beta-1,3-$ D-glucan synthase, a key enzyme for the synthesis of the fungal cell wall, belonging to EC class 2.4 of glycosyltransferases.

A further 20 sequences showed similarity to previously identified proteins that have no known enzymatic activity (Fig. 1; Table 1). Eight of these clones (487, 526, 546, 838, 860, 1094, 1096 , and 1200) aligned with proteins annotated as or reported to be cell wall proteins. Clone 487 resembled extracellular serine or threonine-rich proteins such as Schizosaccharomyces pombe Adg2p, a putatively GPI-anchored extracellular protein that is expressed in a cell-cycle-dependent manner and which mediates cell separation (Alonso-Nunez et al. 2005). Clone 526 encoded a sequence that is mainly low complexity and showed similarity to structural cell wall proteins (Coronado et al. 2007). Clones 546 and 838, although discrete unigenes, both grouped with clock-controlled protein ccg-6 from Neurospora crassa, induced by light and during conidial develop-

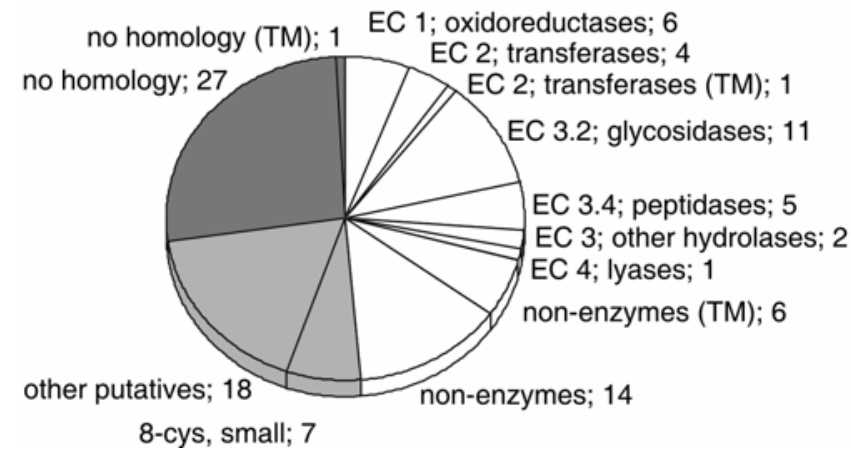

Fig. 1. Division of yeast signal sequence trap unigenes. White sectors: genes with similarity to database entries with known or predicted function, enzymes subdivided by EC classification. Light-gray sectors: genes with similarity to database entries with unknown function, subdivided into those with eight cysteines and others. Dark-gray sectors: genes without similarity to database entries. Proteins containing transmembrane helices are plotted as individual subgroups. 
ment (Bell-Pedersen et al. 1996). Clone 1094 showed similarity to lustrin A, a matrix protein of molluscan shells and pearl (Shen et al. 1997). The two clones 860 and 1096 may contribute to the function of the appressorial cell wall. Clone 860 was similar to $C$. gloeosporioides wax-induced appressorial wall protein CAP22 (Hwang and Kolattukudy 1995) and clone 1096 was similar to the GPI-anchored cell wall protein FEM1 from $F$. oxysporum (Schoffelmeer et al. 2001) and its $M$. grisea homolog, EMP1, expressed during and important for appressorium formation (Ahn et al. 2004). Finally, clone 1200 showed similarity to several antigenic cell wall mannoproteins, such as CwpA from Aspergillus niger (Damveld et al. 2005). Two other proteins identified in the screen are known to be associated with but not physically linked to fungal cell walls. Clone 878 represented a member of class II hydrophobins, a family of conserved ascomycetous surface proteins important for conidiation, germination, and appressorium development (Kim et al. 2005). Clone 1091 exhibited similarity to cerato-platanin from Ceratocystis fimbriata, a fungal surface protein that induces necrosis and elicits phytoalexin synthesis in plants (Pazzagli et al. 1999). Four clones encoded putative transmembrane transporters: two transporters (clones 803 and 1209) belonging to the Major Facilitator Superfamily-Sugar Porter Family (Transporter Classification class TC 2.A.1.1), a Golgi GDP-mannose transporter (clone 990) (TC 2.A.7.13), and a peptide transporter (clone 782) (TC 2.A.67.1). Clone 220 encoded a protein with similarity to the RING domain-containing transmembrane component of the HRD ubiquitin ligase complex involved in endoplasmic reticulum-associated degradation of misfolded proteins (Hampton et al. 1996). Clone 252 encoded a member of a widely conserved group of transmembrane proteins involved in stress sensing, exemplified by its founding member blt101 (Goddard et al. 1993).

The encoded peptides of a group of 25 unigenes showed similarities to diverse putative proteins from genome sequences but not to proteins with a reported or annotated function (Fig. 1). Best matches were found mainly in $M$. grisea $(n=7), F$. graminearum $(n=6)$, and $N$. crassa $(n=5)$. The homologs of 14 of these clones $(130,765,789,848,855,893,1031,1033$, $1068,1083,1124,1135,1137$, and 1207) shared the characteristics of being small ( 93 to 245 amino acids) and relatively rich in cysteine (4 to 11 residues). The functionally annotated homologs to five additional clones $(252,546,860,878$, and 1091) (Table 1) also shared these features.

The remaining 28 unigenes could not be classified by similarity to known or putative proteins (Fig. 1). For some clones, this resulted from the small size of the encoded peptides (clones 39, 156, 545, 819, 861, 1085, 1111, 1121, and 1166), which had inserts encoding less than 20 residues and thus mainly composed a sequence that functioned as a signal peptide in the YSST screen.

After screening the YSST clones against known proteins, we also searched for the presence of conserved domains (Supplementary Table 3), using the National Center for Biotechnology Information (NCBI) Conserved Domain Database. Conserved domains were detected in 24 sequences, exclusively from the set of clones showing similarity to known genes. All identified domains confirmed the results from the protein-Blast analysis.

\section{Expression of genes encoding secreted proteins.}

Using macroarray hybridization, we examined transcript levels of all genes identified by YSST during in vitro cultivation and defined phases of the infection process ex planta (germination and appressorium differentiation) and in planta (biotrophic and necrotrophic development). In addition to PCR products from all YSST cDNAs, those from the reference genes $\alpha$-actin and histone $\mathrm{H} 3$ of Colletotrichum graminicola and the reference genes actin 1 , histones $\mathrm{H} 2 \mathrm{~A}$ and $\mathrm{H} 4$, and ribosomal protein $\mathrm{S} 11$ of maize were spotted onto nylon membranes, and single-stranded $\alpha-{ }^{33} \mathrm{P}$-labeled cDNA probes generated from mRNAs of different in vitro cultures and infected plant tissues were hybridized to the membranes. One medium used for in vitro cultivation was exactly the same as the one used to grow cultures for RNA isolation and construction of the YSST library (i.e., minimal medium that did not contain any carbon sources besides those included in soluble corn leaf extract and purified corn cell walls). The other two media included glucose as the only carbon source in one case and soluble corn leaf extract plus purified corn cell walls plus glucose in the other. Comparison of these culture conditions allowed us to analyze whether host-derived molecules may have induced the expression of certain genes, and if the expression of some of these genes is subject to catabolite repression. Probes analyzing in planta expression of genes were derived from leaf samples harvested at 16, 24, 48, 72, and $120 \mathrm{~h}$ postinoculation (hpi). One control was taken directly after inoculation (0 hpi) and one mock-inoculated control was also included.

Data were corrected for background hybridization and differences between the blots. Signals from 99 YSST unigenes resulted from at least one of the three probes derived from the in vitro cultures, and 97 unigenes were detected by at least one probe from the infection time course. The fungal reference genes $\alpha$-actin and histone $\mathrm{H} 3$ are considered to be constitutively expressed. The signals for these genes, expressed as relative abundances compared with the 0 hpi timepoint, suggested that the fungal biomass in the infected leaf did not change significantly up to $48 \mathrm{hpi}$, corresponding to germination and appressorium formation, followed by the biotrophic growth phase, but increased rapidly during the subsequent necrotrophic growth phase (Fig. 2A, first and second panels). To discriminate between putative differential expression and the general increase in transcript abundance due to fungal growth, hybridization signals were corrected for fungal biomass by calibration against the average of the aforementioned fungal reference genes. After calibration, values for both transcripts fluctuated by, at most, \pm 0.4 relative units around the mean (Fig. $2 \mathrm{~A}$, third and fourth panels). Treating the in vitro cultures and the infection time course as separate datasets, the biomass-calibrated values of each clone were expressed as fold abundance compared with the lowest value in each dataset. The in planta expression profiles of 24 clones that produced consistent signals were classified as "constitutive," "early," "late," or "biphasic" (Fig. 2B through D). These clones represent eight enzymes, five nonenzymes, six putatives, and seven without homology (Fig. 1). Profiles for several other genes were not consistent due to low transcript abundances.

Four genes showed relatively constitutive expression during infection (Fig. 2B). Twelve genes had a peak of transcript abundance at a specific time, which varied from early to late phases of pathogenesis (Fig. 2C). Eight genes had two expression maxima, one correlating with the biotrophic and another with the necrotrophic phase of infection (Fig. 2D). The macroarray hybridization thus indicated that the vast majority of genes identified by the YSST screen is indeed expressed during pathogenesis in planta, and many of them in a regulated manner. Genes encoding functionally or structurally similar proteins usually show different expression patterns, indicating a role at different phases of pathogenesis regardless of their similarity.

For the in vitro cultures, distinct expression patterns were also observed. In the culture grown on corn cell walls and extract, expression of 60 unigenes was increased at least twofold compared with glucose as the sole carbon source. Of these induced genes, 41 showed a decrease in expression by at least $50 \%$ in the corn 
cell wall and extract containing culture with glucose added, suggesting that expression of these genes was repressed by glucose (e.g., clones 891, 1061, and 1088). The expression of 19 induced genes was increased in the presence of corn components regard- less of the presence or absence of glucose (e.g., clones 838,848 , and 869). The remaining genes exhibited similar expression under all conditions or were expressed more strongly only in glucose or only in the mixed culture.

A

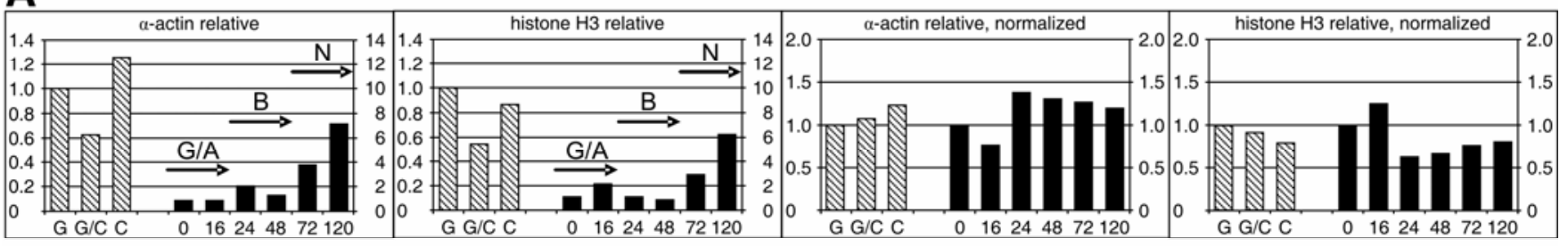

B

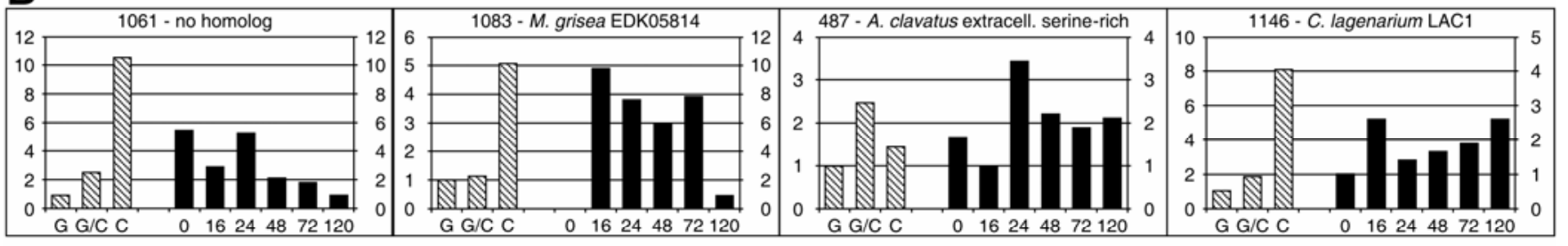

C

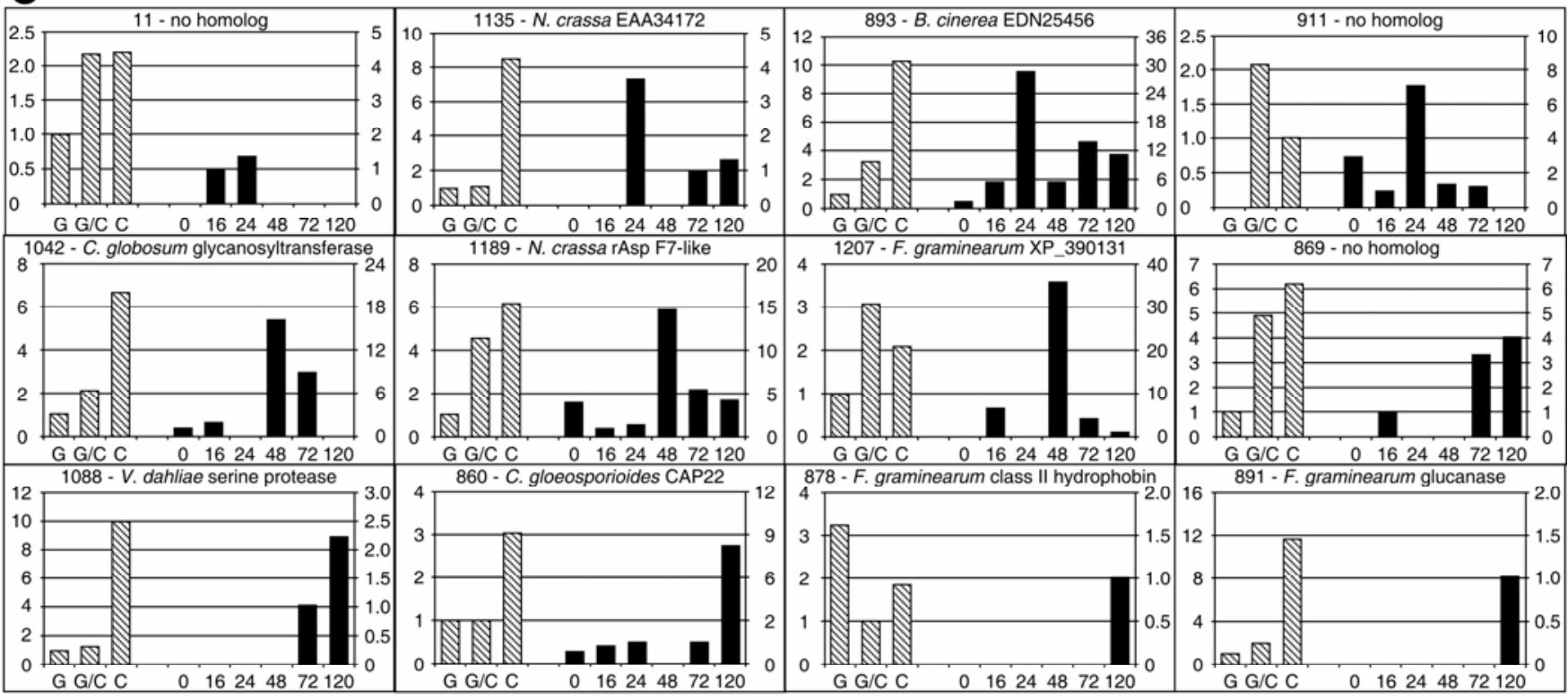

D

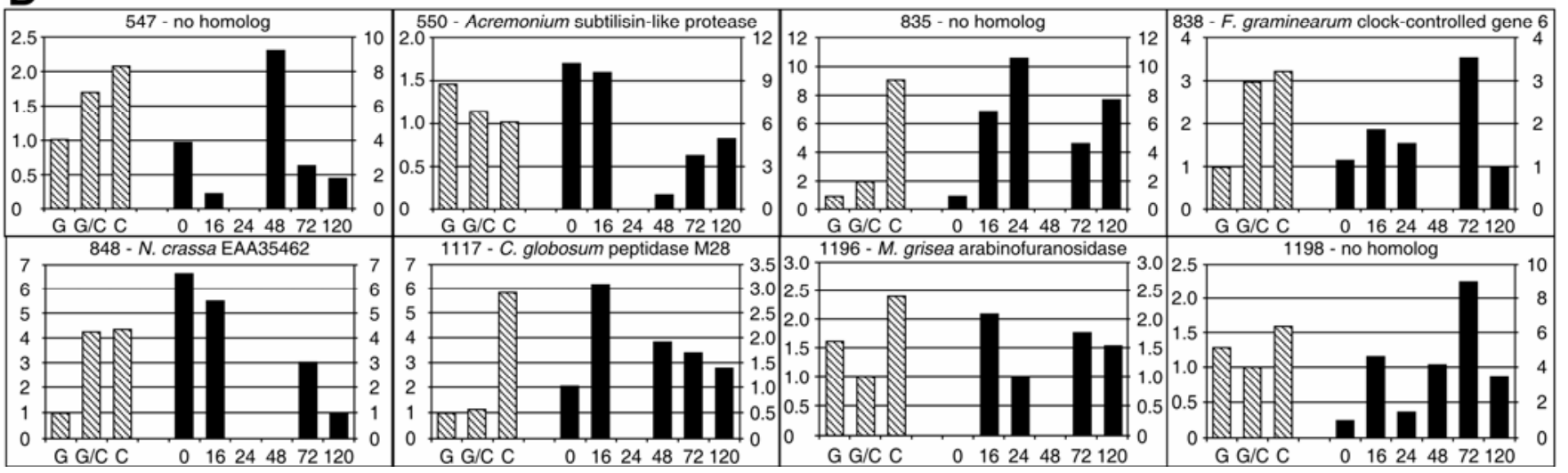

Fig. 2. Macroarray analysis of yeast signal sequence trap (YSST) clones. A, Expression profiles of fungal reference genes $\alpha$-actin and histone H3; comparison of expression profiles before (first and second panel, "relative") and after (third and fourth panel, "relative, normalized") calibration for fungal biomass. Arrows indicate phases of fungal development. G/A: germination and appressorium formation; B: biotrophic phase; N: necrotrophic phase. B through D, Biomass-calibrated expression profiles of YSST clones. B, Clones expressed "constantly". C, clones expressed "early" to "late". D, clones expressed "biphasically". Hatched bars, left Y-axis: expression in vitro with glucose (G), glucose + corn components (G/C), or corn components alone (C) as carbon source. Solid bars, right Y-axis: expression in planta at $0,16,24,48,72$, and $120 \mathrm{~h}$ postinoculation (hpi). Y-axes show fold expression with respect to the lowest value in vitro and in planta, respectively. A, For the reference genes, in vitro glucose (G) and in planta 0 hpi (0) were set to 1. 
We applied qRT-PCR on a selection of eight unigenes (clones 487, 869, 878, 893, 911, 1088, 1146, and 1189) and the reference genes $\alpha$-actin and histone H3 of $C$. graminicola to validate the observed expression patterns by an independent approach. The unigenes were chosen in a way that each of the three classes defined in Figure 1 but also different expression patterns obtained by macroarray hybridizations in planta (Fig. $2 \mathrm{~B}$ through D) were represented. As template, we used new RNA preparations to analyze the same controls and timepoints as described above and additionally included RNAs for 8 and 36 hpi to better resolve the expression kinetics. The qRT-PCR data were processed analogous to the macroarray data and biomass-corrected values are again presented as fold abundance relative to the lowest value of that gene for in vitro and infection series, respectively, to achieve maximum comparability between macroarray and qRT-PCR results.

For most genes tested, biomass-corrected expression levels obtained by qRT-PCR (Fig. 3A and B) corresponded with those obtained by macroarray hybridization. Only clone 487 showed a major discrepancy between the two methods, appearing rather constantly expressed in the macroarray but upregulated late in qRT-PCR. However, for this clone, the standard deviations in the qRT-PCR data were rather large and did not improve when a redesigned primer pair was used (data not shown). To control for fungal genomic DNA in the RNA preparations, which could generate false signals if present, the primers for histone $\mathrm{H} 3$ were designed to include an intron. For this control, we loaded the reaction products of a qRT-PCR experiment onto an agarose gel (Fig. 3C). A preparation of fungal genomic DNA produced the expected fragment including the intron, whereas all RNA preparations used in the qRT-PCR experiments produced only the smaller, spliced fragment. Additional controls lacking the template or including RNA isolated from uninfected maize did not show any amplification product.

When comparing expression profiles of the genes with their expected function during the infection process, no correlation became evident. Expression patterns ranged from almost constant to defined peaks, and examples of the different patterns were found in most groups of genes presented in Figure 1. For instance, the expression of certain genes encoding small proteins with eight cysteines (clones 1135 and 1207) peaked during biotrophy (Fig. 2C). In contrast, the expression of other genes with these features (clones 860 and 878) peaked during necrotrophy (Fig. 2C). Similarly, a serine protease (clone 1088) was expressed late (Fig. 2C), whereas the expression profiles of a subtilisin-like protease (clone 550) and a member of peptidase family M28 (clone 1117) were biphasic (i.e., expression was observed at early and late stages of pathogenesis) (Fig. 2D).

\section{DISCUSSION}

Plant-pathogenic fungi and Oomycota secrete various effector proteins to establish and maintain a compatible interaction

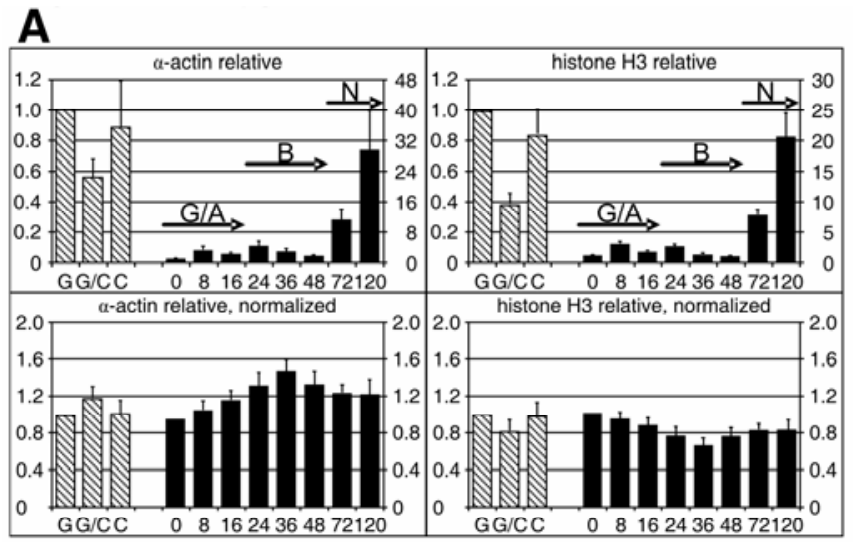

B
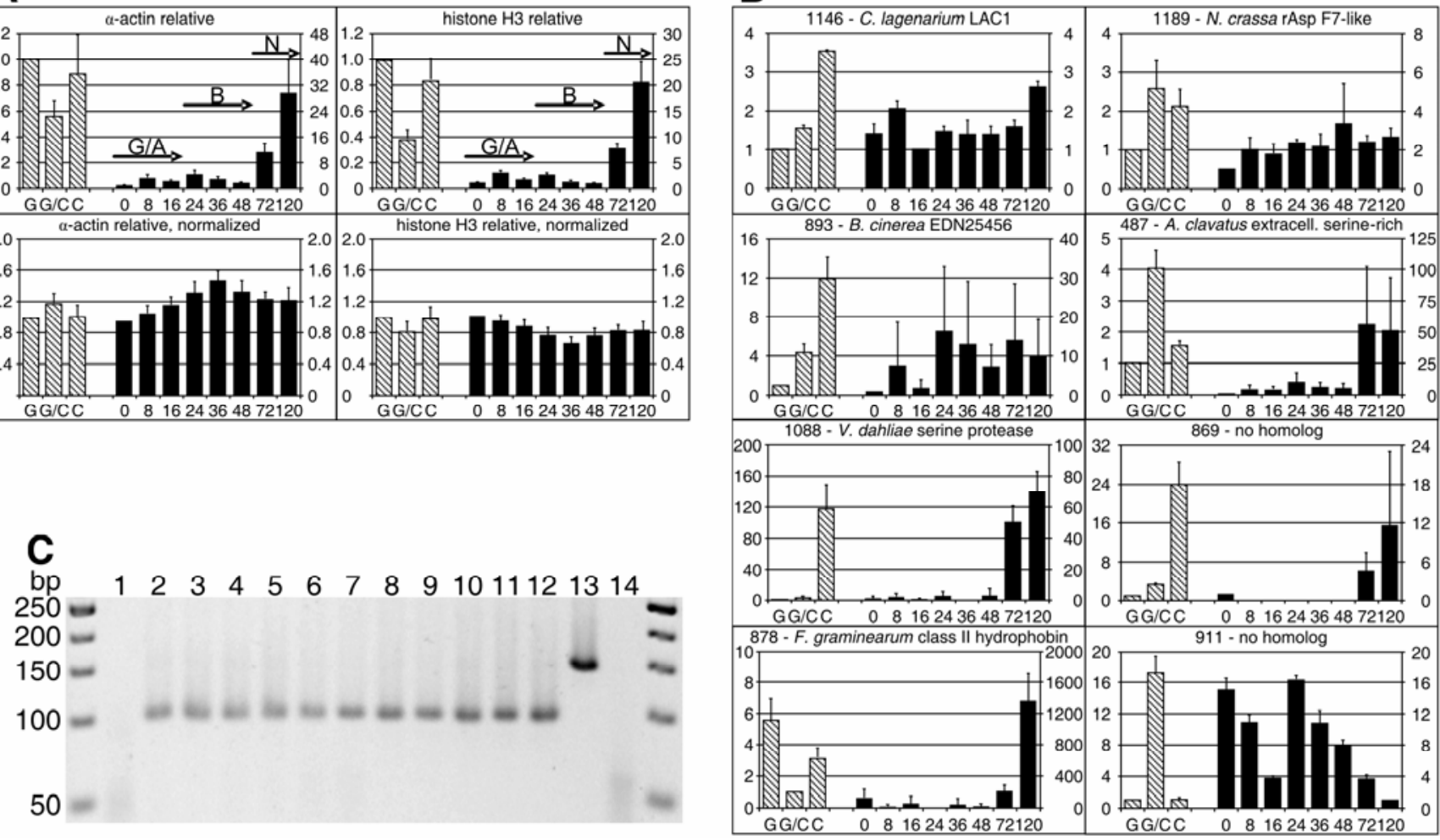

Fig. 3. Quantitative reverse-transcriptase polymerase chain reaction (qRT-PCR) analysis of yeast signal sequence trap (YSST) clones. A, Expression profiles of fungal reference genes $\alpha$-actin and histone H3; comparison of expression profiles before (upper panels, "relative") and after (lower panels, "relative, normalized") calibration for fungal biomass. Arrows indicate phases of fungal development. G/A: germination and appressorium formation; B: biotrophic phase; N: necrotrophic phase. B, Biomass-calibrated expression profiles of YSST clones. Hatched bars, left Y-axis: expression in vitro with glucose (G), glucose + corn components (G/C), or corn components alone (C) as carbon source. Solid bars, right Y-axis: expression in planta at 0, 8, 16, 24, 36, 48, 72, and 120 h postinoculation (hpi). Yaxes show fold expression with respect to the lowest value in vitro and in planta, respectively. A, For the reference genes, in vitro glucose (G) and in planta 0 hpi (0) were set to 1 . Values are means with standard deviations of three replicates. Because replicates were transformed to relative values before calculation of means and standard deviations (SD), the samples set to 1 have no SD. C, Agarose gel of RT-PCR reactions for fungal reference gene histone H3. Lane 1: RNA from noninoculated corn leaves; lanes 2 through 9: RNAs from corn leaves inoculated with Colletotrichum graminicola harvested at 0, 8, 16, 24, 36, 48, 72, and 120 hpi, respectively; lanes 10 through 12: RNAs from mycelia grown in vitro with, glucose, glucose plus corn components, and corn components alone, respectively, as carbon sources; lane 13: control reaction on genomic DNA of C. graminicola; lane 14: no-template control. 
with their host (Catanzariti et al. 2007; Jones and Dangl 2006). The recent annotation of whole genome sequences of some of these organisms allowed the extraction of all putatively secreted proteins from a translated proteome by bioinformatics. In addition to in silico prediction, functional screens like the YSST, employed in this study, can be applied to identify the secretome. For organisms such as $C$. graminicola that do not as yet have annotated proteomes, YSST is an effective approach for discovering larger parts of their secretome.

During the biotrophic phase, $C$. graminicola does not proliferate but rather remains locally restricted (Bergstrom and Nicholson 1999) and, therefore, makes up only a small proportion of the biomass of the infected tissue. This was verified by our time course qRT-PCR experiments with constitutively expressed fungal $\alpha$-actin and histone $\mathrm{H} 3$ genes (Fig. 3A). Their transcript abundances remained relatively constant during the biotrophic phase and just started to increase after the shift to necrotrophy when the fungus began to proliferate. However, during the initial phase of pathogenesis, the compatibility of the interaction is established, and fungal-secreted proteins are assumed to play an essential role in this process. A previous YSST screen with $P$. infestans-infected tomato leaves identified 23 unigenes from the oomycete and 22 from the host (Lee et al. 2006). In preliminary attempts to construct a YSST library from RNA isolated from infected corn leaves, clones of fungal origin were strongly underrepresented; therefore, we decided to use fungal mycelia growing in minimal medium supplemented with host factors (i.e., a combination of cell wall fragments and soluble cell free leaf extract). Including host factors into the growth medium hypothetically led to the induction of fungal genes that would be expressed during in planta growth. An analogous proteomic analysis with the cereal pathogen $F$. graminearum recently led to the identification of fungal secreted proteins that were not detected when using glucose as the sole carbon source (Phalip et al. 2005). The results of our macroarray and qRT-PCR analyses confirm that the vast majority of the genes identified by YSST exhibit significantly higher expression levels on media supplemented with corn compounds than on media containing glucose. Thus, the analyses of gene expression suggest that unknown host molecules in the supplemented medium were perceived by $C$. graminicola and transduced into a transcriptional output which includes a large number of genes encoding secreted proteins.

For two plant-pathogenic Ascomycota with annotated proteomes, in silico prediction suggested that their secretomes may comprise 739 proteins in the case of $M$. grisea (Dean et al. 2005), and 1,442 proteins in the case of $F$. graminearum (Cuomo et al. 2007). For M. grisea, proteins were originally predicted as being secreted when both the hidden Markov model and the neural network algorithms implemented in SignalP, plus the ProtComp software, yielded positive results (Dean et al. 2005). When the $M$. grisea proteome was re-analyzed by the same approach that was used for $F$. graminearum (i.e., with the software TargetP), its secretome size increased to 1,491 (Cuomo et al. 2007). These significant differences illustrate some of the difficulties associated with in silico prediction of secretomes. In any case, it is evident that our YSST screen has not retrieved the entire secretome of $C$. graminicola. Reasons for the incompleteness of the identified secretome are severalfold. It is likely that more extensive sequencing would have retrieved additional unigenes. However, due to increasing redundancy, the effort of finding those would have increased unproportionally. Furthermore, a set of genes may exist in $C$. graminicola that cannot be induced in vitro even by addition of the host-derived components. Moreover, signal sequence variants may exist that are insufficiently functional in Saccharomyces cerevisiae, or certain proteins may be toxic. Despite these limitations, the work described here represents one of the largest experimentally determined secretomes identified so far for any fungus. As has been suggested earlier (Lee et al. 2006; Monteoliva et al. 2002), YSST may also retrieve proteins secreted through "nonclassical" pathways, as shown for yeast (Nombela et al. 2006). Analyses of extracellular proteins collected from $F$. graminearum-infected wheat heads suggested that some secreted proteins of this filamentous ascomycete also lacked signal sequences (Paper et al. 2007). It remained unsettled, however, whether these proteins were truly secreted or whether the detection of these proteins in extracellular fluids resulted from fungal lysis occurring during infection. Among the clones obtained by YSST, we found three (data not shown) that lacked significant SignalP and TMHMM scores but were classified as being nonclassically secreted by SecretomeP, a software specialized for predictions of non-classical (i.e., not signal peptide dependent) protein secretion. One of the encoded proteins was similar to S. cerevisiae Av19p, involved in exocytotic transport from the Golgi apparatus. Seven other clones encoding peptides with 99 to 415 residues lacked significant scores with SignalP, TMHMM, and SecretomeP (data not shown). However, their homologs (e.g., heat shock protein 70) are known to be not only intracellularly located but also nonclassically secreted. Others, such as the translation elongation factor 1 or cyclophilin, have been identified in the extracellular space of other fungi (Nombela et al. 2006; Paper et al. 2007). It remains to be confirmed whether such proteins lacking a canonical signal peptide are indeed secreted and whether they play a role in pathogenicity.

Our YSST screen retrieved 103 unigenes carrying signal peptides or transmembrane helices that were validated by the SignalP and TMHMM softwares. Seventy-five unigenes encoded proteins resembling proteins with a known or predicted function or hypothetical proteins. In all cases, the best match for those was found within the Ascomycota. Within this phylum, 58 of the best matches were found in the class Sordariomycetes, to which several proteome-annotated fungi belong (i.e., the plant pathogens $F$. graminearum and $M$. grisea and the saprophytes Chaetomium globosum, N. crassa, and Trichoderma reesei). Interestingly, none of the genes identified here have previously been found in Colletotrichum graminicola. Thus, these recent proteome annotations improved the assignment of many proteins identified here by YSST to their putative homologs in related fungi. However, the remaining 28 unigenes $(27 \%)$ had no features recognizable by any of the software tools used for analysis and, thus, represent novel genes. They either exist only in $C$. graminicola and maybe also in other species of this genus, or they may differ too much from their counterparts in the proteome-annotated Sordariomycetes. These novel proteins may have specialized functions important for the infection of maize or for the hemibiotrophic lifestyle.

Of the 50 unigenes encoding a known or predicted function, seven encode transmembrane proteins, three of which presumably are involved with the uptake of nutrients from the environment. Another 10 of the identified proteins are most likely located in the fungal cell wall or the extracellular matrix which are known to undergo dynamic modifications during pathogenesis of Colletotrichum spp. (El Gueddari et al. 2002; Hutchison et al. 2002; Perfect et al. 2001). Eight of these proteins appear to have structural functions and two are $\beta$-1,3-glycanosyltransferases. Homologs of these enzymes have been reported to be involved in fungal cell wall modification. It remains to be shown whether cell wall modifications occurring at certain phases of pathogenesis are essential for evading putative innate immune responses of the host. The remaining 33 proteins with a predicted function are probably secreted into the surroundings where some of them may interact directly 
or indirectly with host targets. The oxidoreductases, particularly the laccases, may be involved in modification of antifungal compounds or degradation of lignin (Martinez et al. 2005; Schouten et al. 2002). A putative quercetinase, another secreted oxidoreductase, cleaves the O-heteroaromatic ring of the common plant flavonol and antioxidant quercetin, an inhibitor of certain ABC transporters (Yoshikawa et al. 2004) and protein kinases involved in signaling (Lee et al. 2008). Because quercetin also has antifungal properties, quercetinase may be important for the detoxification of plant defense compounds or for interfering with signal transduction processes of the host. With 19 of 30 sequences belonging to EC class 3, the hydrolases are a prominent group of putative enzymes identified in our screen. This is not surprising, because many of these proteins are members of the large group of cell wall-degrading enzymes. During necrotrophic growth, the glycosylhydrolases may liberate sugars from plant cell walls to provide the fungus with carbon sources and support host penetration (You and Chung 2007). Other glycosylhydrolases such as tomatinase may represent candidate suppressors of host defense response (Bouarab et al. 2002). The peptidases may have functions in extracellular processing of fungal secreted proteins (MartinezRuiz et al. 1997), degradation of proteinaceous components involved in the plant pathogen response (Olivieri et al. 2002), or degradation of host tissue, providing nitrogen (Carlile et al. 2000). Both glycosylhydrolases and peptidases could also weaken cell walls, allowing for an easier access to host cells.

The macroarray and qRT-PCR analyses revealed that, upon inoculation and penetration of the host by $C$. graminicola, no significant fungal growth in the corn leaves is observed for a period of at least 2 days, because the absolute amounts of transcripts for constitutively expressed fungal reference genes remained constant over this period of time. At 4 days after inoculation, the absolute transcript levels had increased sharply and had risen further at the fifth day. This growth pattern reflects the hemibiotrophic lifestyle of $C$. graminicola, in which an initial, biotrophic phase without major proliferation is followed by a necrotrophic phase with pronounced fungal development. Using the average of the values for the fungal reference genes $\alpha$-actin and histone $\mathrm{H} 3$ as calibrator, the expression data for all genes were corrected for fungal biomass to reveal actual differential expression, both for the macroarray and the qRT-PCR data. For seven of eight genes analyzed by qRT-PCR, the expression patterns obtained were highly similar to those obtained by macroarray analysis. For one gene, the results were inconsistent and the discrepancy could not be resolved, as mentioned before. Generally, in hybridizationbased assay using labeled total cDNA, such as the macroarray analysis described here, cross-hybridization due to the occurrence of gene families cannot be excluded entirely. For some genes, this may lead to minor discrepancies between array data and data from highly sequence-specific PCR-based methods. Several types of expression patterns occurred in planta. Some genes appeared constitutively expressed whereas others exhibited a single maximum at a certain phase of infection and others exhibited a biphasic expression with two maxima. When comparing these patterns to the blast-based classification of the genes (enzyme, known nonenzyme, homolog to putative, or without homolog) (Fig. 1) and to functional (e.g., glycosyl hydrolase or protease) or structural features (e.g., cysteine rich or structural cell wall proteins), no group of genes shows a clear bias in expression patterns among its members, suggesting that various members of the different classes of proteins function at different times during infection. Therefore, it is likely that the fraction of the secretome from $C$. graminicola that is expressed during the biotrophic phase differs to some extent from that expressed during the necrotrophic phase. At this point, however, it is not yet possible to clearly identify genes that are specific for either the biotrophic or the necrotrophic phase or the switch between them. This may be due to the fact that infection structure differentiation ex planta and in planta does not occur perfectly synchronously. Green fluorescent protein tagging of the candidate genes identified here will help identify genes specifically expressed at defined stages of pathogenesis, clearly distinguishing biotrophic- from necrotrophic-induced genes. Identification of such biotrophy and necrotropy markers will allow stringent statistical analysis of expression patterns.

Several of the unigenes retrieved by our YSST screen may play important roles during specific stages of pathogenesis, particularly among those for which no function or homolog is found at present. Functions for these proteins as pathogenicity or virulence determinants and in regulation of hemibiotrophy of the corn pathogen $C$. graminicola will be assessed by targeted gene inactivation approaches. This should considerably add to the list of genes known to be required for the development of maize anthracnose and stalk rot such as chitin synthase (Werner et al. 2007) and CPR1, a subunit of the signal peptidase (Thon et al. 2002), that were previously identified in this fungus.

\section{MATERIALS AND METHODS}

\section{Cultivation of $C$. graminicola, $S$. cerevisiae,} Escherichia coli, and Zea mays.

Wild-type strain M2 of Colletotrichum graminicola (Ces.) G. W. Wilson was cultured on oat-meal-agar plates at $23^{\circ} \mathrm{C}$ under UV light (Philips TLD36W/08, Hamburg, Germany). Conidia were harvested from 2- to 3-week-old plates in distilled water and washed three times. The final concentration of conidia was adjusted to $10 \% \mathrm{ml}$ in $0.01 \%$ Tween 20 for spray inoculation of maize or in water for inoculation of liquid cultures. The latter consisted of $50 \mathrm{ml}$ of complete medium (yeast extract at $1 \mathrm{~g} / \mathrm{liter}$; casein hydrolysate at $1 \mathrm{~g} / \mathrm{liter}$; glucose at 10 $\mathrm{g} /$ liter; a 100 -g/liter $\mathrm{Ca}\left(\mathrm{NO}_{3}\right)_{2}$ stock solution at $10 \mathrm{ml} / \mathrm{liter}$; and a 10 -ml/liter stock solution containing $\mathrm{KH}_{2} \mathrm{PO}_{4}$ at $20 \mathrm{~g} / \mathrm{liter}$, $\mathrm{MgSO}_{4}$ at $25 \mathrm{~g} / \mathrm{liter}$, and $\mathrm{NaCl}$ at $5.4 \mathrm{~g} / \mathrm{liter}$ ) in 300-ml Erlenmeyer flasks that was inoculated with $10^{5}$ conidia. Cultures were incubated at room temperature under orbital shaking at $20 \mathrm{rpm}$. After 5 days, the medium was removed, whereas the mycelium was washed and resuspended in $50 \mathrm{ml}$ of sterile distilled water and then incubated at room temperature under orbital shaking at $20 \mathrm{rpm}$. After $12 \mathrm{~h}$, the water was poured off and the mycelium was washed once with sterile distilled water and then resuspended in $50 \mathrm{ml}$ of minimal medium $\left(\mathrm{KH}_{2} \mathrm{PO}_{4}\right.$ at $1.0 \mathrm{~g} /$ liter, $\mathrm{KNO}_{3}$ at $1.0 \mathrm{~g} / \mathrm{liter}, \mathrm{MgSO}_{4} \times 7 \mathrm{H}_{2} \mathrm{O}$ at $0.5 \mathrm{~g} /$ liter, $\mathrm{KCl}$ at $0.5 \mathrm{~g} /$ liter, and $6.0 \mathrm{mM} \mathrm{NaOH}$ ) containing either $1.5 \%$ glucose or $1.5 \%$ glucose plus $1.5 \%$ (wt/vol) corn cell walls plus $1.5 \%$ ( $\mathrm{vol} / \mathrm{vol})$ soluble corn leaf extract or $1.5 \%(\mathrm{wt} / \mathrm{vol})$ isolated corn cell walls plus $1.5 \%$ ( vol/vol) soluble corn leaf extract as carbon sources. For harvest, the mycelium was washed once with sterile distilled water and blotted dry on paper towels, shock frozen in liquid nitrogen, and stored at $-70^{\circ} \mathrm{C}$. The cell walls were isolated from $200 \mathrm{~g}$ of chopped stems and leaves of 4-week-old corn plants as published (Sposato et al. 1995), except that the dried fibers were finally ground to a powder for $1 \mathrm{~min}$ at $30 \mathrm{~Hz}$ in a TissueLyser, using 50-ml stainless steel milling vessels with $30-\mathrm{mm}$ stainless steel balls (Qiagen, Hilden, Germany). Cell-free, soluble extract was prepared from leaves of 3-week-old corn plants. The leaves (110 g) were homogenized in $100 \mathrm{ml}$ of ice-cold potassium phosphate buffer, $\mathrm{pH} 7.0$, in a Waring blender. The homogenate was centrifuged at $25,000 \times g$ and $4^{\circ} \mathrm{C}$ for $25 \mathrm{~min}$. The supernatant was successively filtered through Miracloth and coarse 
and fine filter papers, and finally filter sterilized through a 0.2$\mu \mathrm{m}$ filter. The addition of buffer resulted in a dilution of the extract by $50 \%$.

Zea mays cv. Mikado (KWS Saat AG, Einbeck, Germany) was raised in the greenhouse in steamed garden soil in pots with a diameter and a height of $8.5 \mathrm{~cm}$ at a temperature of 22 to $30^{\circ} \mathrm{C}$ and ambient humidity. Four seeds per pot were sown. The pots were distributed in a randomized manner and their positions were exchanged once a week. Two days before inoculation, 12-day-old plants were transferred to an environmentally controlled growth chamber (model AR-75L; Percival Scientific, Boone, IA, U.S.A.) with a cycle of 16 and $8 \mathrm{~h}$ of light and darkness, respectively. Illumination was $200 \mu \mathrm{E} \mathrm{m}^{-2} \mathrm{~s}^{-1}$ at soil level; humidity and temperature were $50 \%$ and $25^{\circ} \mathrm{C}$ during light and $70 \%$ and $20^{\circ} \mathrm{C}$ during darkness. After inoculating the fungus, humidity and temperature were kept at $100 \%$ and $25^{\circ} \mathrm{C}$ for $24 \mathrm{~h}$, then returned to the previous values. For inoculation, each plant was sprayed with $1.7 \mathrm{ml}$ of conidial suspension. Samples of three leaves per plant were taken before inoculation and at the indicated timepoints after inoculation, shock frozen in liquid nitrogen, and stored at $-70^{\circ} \mathrm{C}$.

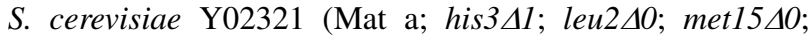
ura3 $\Delta 0$; YIL162w::kanMX4) (Euroscarf, Frankfurt, Germany) was cultured on YPD medium for maintenance (Ausubel et al. 1994). For auxotrophic selection, synthetic complete medium lacking the selective amino acid leucine $\left(\mathrm{SC} / \mathrm{leu}^{-}\right)$was used (Ausubel et al. 1994). Solid media contained 1.8\% (wt/vol) Difco agar (BD, Heidelberg, Germany).

\section{Nucleic acid manipulations.}

Standard techniques were performed as described (Ausubel et al. 1994). For all nucleic acid isolation procedures, fungal and plant material was first ground to a fine powder under liquid nitrogen using mortar and pestle. Large-scale isolation of total RNA from mycelium was performed as reported (Chomczynski and Sacchi 1987). Total RNA from corn leaves was prepared using the peqGOLD plant RNA kit (Peqlab Biotechnologie GmbH, Erlangen, Germany). Poly $\mathrm{A}^{+}$-RNA was isolated using the OligoTex mRNA Midi kit (Qiagen). All primers used are listed in Supplementary Table 4.

\section{Generation and screening of the YSST library.}

Equal amounts $(1.5 \mu \mathrm{g})$ of mRNA from mycelia grown on minimal medium containing $1.5 \%$ (wt/vol) corn cell walls plus $1.5 \%$ ( $\mathrm{vol} / \mathrm{vol})$ soluble corn leaf extract for 22,44 , and $66 \mathrm{~h}$ were mixed and first-strand cDNA was synthesized on the pool using the SuperScript double-stranded cDNA synthesis kit (Invitrogen, Carlsbad, CA, U.S.A.) and a custom random nonamer oligonucleotide (NotI-N9), designed to yield cDNA with a 3'-NotI restriction site for directional cloning in plasmid pSMASH (Goo et al. 1999b). After secondstrand synthesis and blunting, the double-stranded cDNA was ligated to an EcoRI adapter. The adapter was produced by annealing two custom complementary oligonucleotides (Multilinker-up and -low) at a concentration of $0.5 \mathrm{mM}$ each in $50 \mu \mathrm{l}$. Adapter-ligated cDNA was fractionated on an agarose gel and a fraction from approximately 200 to 2,500 bp was isolated. Plasmid pSMASH was digested with EcoRI and NotI and purified using the Qiagen PCR purification kit. Gel-purified cDNA was ligated into the digested vector and aliquots of the ligated DNA were transformed into Escherichia coli ElectroTen-Blue electrocompetent cells according to the manufacturer's protocol (Stratagene, Amsterdam). After recovery in SOC medium (Ausubel et L. 1994), cells were plated on Luria-Bertani (LB) plates with $150 \mathrm{mM}$ ampicillin and incubated at $37^{\circ} \mathrm{C}$ overnight. Colonies were collected by washing with liquid LB medium.
Preparation of chemocompetent yeast cells and transformation by the high-efficiency lithium acetate method was performed as described (Gietz and Woods 2002). Cells were grown on $\mathrm{SC} / \mathrm{leu} \mathrm{u}^{-}$medium containing $2 \%(\mathrm{wt} / \mathrm{vol})$ sucrose and $0.025 \%(\mathrm{wt} / \mathrm{vol})$ glucose at $30^{\circ} \mathrm{C}$ for 3 to 5 days. The addition of an optimized low amount of glucose reduces background growth resulting from expression of cytoplasmic invertase (Jacobs et al. 1999). Positive colonies from the primary selection plates were resuspended in liquid $\mathrm{SC} / \mathrm{leu}^{-} / 2 \%$ glucose in 96-well microtiter plates containing a sterile 2-mm glass bead in each well and grown to stationary phase overnight at $30^{\circ} \mathrm{C}$ and $250 \mathrm{rpm}$. Aliquots of these cultures were diluted in distilled water to a density of approximately $10^{3}$ cells $/ \mathrm{ml}$ and 50 $\mu \mathrm{l}$ was spread on $\mathrm{SC} / \mathrm{leu}^{-}$medium containing $2 \%$ sucrose and antimycin $\mathrm{A}$ at $2 \mu \mathrm{g} / \mathrm{ml}$. The latter inhibits oxidative respiration and thereby forces yeast to rely on fermentation for growth, thus facilitating the elimination of false positives. Plates were incubated at $30^{\circ} \mathrm{C}$ for 3 to 5 days.

\section{Amplification and sequencing of cDNA inserts.}

Using crude sodium dodecyl sulfate (SDS) lysates of yeast transformants (Akada et al. 2000), cDNA inserts were amplified in 96-well microtiter plates. PCR reactions had a volume of $25 \mu \mathrm{l}$ and contained $1 \mu \mathrm{l}$ of lysate as template, primers ScADH.F1 and ScSUC2.R2 at $0.2 \mu \mathrm{M}$ each, $0.2 \mathrm{mM}$ dNTPs, $2.5 \mu \mathrm{l}$ of ThermoPol buffer, and 0.5 units of Taq DNA polymerase (New England Biolabs GmbH, Frankfurt a. M., Germany). Cycling conditions were $94^{\circ} \mathrm{C}$ for $1 \mathrm{~min}$ and 35 cycles of $94^{\circ} \mathrm{C}$ for $30 \mathrm{~s}, 61^{\circ} \mathrm{C}$ for $30 \mathrm{~s}$, and $72^{\circ} \mathrm{C}$ for $2 \mathrm{~min}$ followed by $72^{\circ} \mathrm{C}$ for $5 \mathrm{~min}$ and a hold at $16^{\circ} \mathrm{C}$. PCR fragments were purified using the QIAquick 96 PCR purification kit (Qiagen). For sequencing using the BigDye Terminator v1.1 cycle sequencing kit (Applied Biosystems, Foster City, CA, U.S.A.), $10 \mathrm{ng}$ of each fragment was used in a $10-\mu \mathrm{l}$ reaction with $2 \mu \mathrm{l}$ of Terminator ready reaction mix, $1 \mu \mathrm{l}$ of $5 \times$ BigDye sequencing buffer, and 3.2 pmoles of oligonucleotide ScADH.F1 or ScSUC2.R2 as primer. Cycling parameters were as suggested by the manufacturer. Sequence reactions were purified using the Qiagen DyeEx 96 kit and analyzed on an Applied Biosystems 3130xl genetic analyzer.

In early rounds of screening, certain sequences were frequently found. Therefore, the crude lysates from positive yeast transformants were first analyzed by a multiplex PCR assay to eliminate such clones from subsequent experiments. We used ScADH.F1 as forward primer and a mix of seven specific reverse primers: 28S-test, 18S-test, 3326-test, 9844-test, 124test, 465-test, and 494-test. Each primer was added to $0.2 \mu \mathrm{M}$; reaction setup and cycling conditions were as above.

The assembly of sequence reads was performed with the software Lasergene SeqMan II (DNASTAR, Inc., Madison, WI, U.S.A.). Identified unigenes were checked for the presence of putative secretion signal peptides or transmembrane helices using SignalP 3.0 and TMHMM, respectively. Putative homologs of the unigenes were identified in GenBank by blastp and tblastx searches. Conserved domains were identified using the NCBI Conserved Domain search on the CDD database.

\section{Macroarray production and hybridization.}

Inserts from YSST clones were amplified in four parallel 50$\mu \mathrm{l}$ reactions with primers ScADH.F1 and ScSUC2.R2 at $1 \mu \mathrm{M}$ each, $0.2 \mathrm{mM}$ dNTPs, $5 \mu \mathrm{l}$ of ThermoPol buffer, 2 units of Taq DNA polymerase, and $1 \mu \mathrm{l}$ of lysate or purified PCR product as template. A fragment of the $C$. graminicola histone $\mathrm{H} 3$ gene (AM944495) was amplified to serve as fungal reference. As a second fungal reference, a fragment of the $\alpha$-actin gene of $C$. graminicola (AM944496) was used. For maize, actin 1, histone $\mathrm{H} 2 \mathrm{~A}$ and $\mathrm{H} 4$, and ribosomal protein $\mathrm{S} 11$ were chosen as refer- 
ence genes (accessions J01238.1, BT019008.1, M13377.1, and BT016344.1). In all cases, cycling conditions were as described for insert-amplification from SDS lysates. Spotting of purified PCR fragments was performed as previously described and generated subarrays with four double-spotted fragments in a three-by-three pattern, with the center position left empty (Sreenivasulu et al. 2002).

Hybridization probes, consisting of ${ }^{33} \mathrm{P}$-labeled secondstrand cDNA, were prepared from total RNA as described (Sreenivasulu et al. 2002), including published modifications (Zierold et al. 2005). Probe synthesis was repeated four times on the same first-strand cDNA, using $\alpha{ }^{3}{ }^{33} \mathrm{P}-\mathrm{dATP}$ in addition to $\alpha-{ }^{33} \mathrm{P}-\mathrm{dCTP}$ to increase probe activity. The resulting probes were pooled and filtered using $0.2-\mu \mathrm{m}$ Anapore membrane VectaSpin microcentrifuge filters (Whatman Ltd., Maidstone, U.K.).

Hybridization was performed as described (Zierold et al. 2005), with modified duration $(22 \mathrm{~h})$. Washed membranes were placed in Saran wrap and exposed to Fujifilm MS imaging plates and scanned on a Fuji BAS3000 phosphoimager (Fujifilm Corp., Tokyo).

The obtained images were analyzed using the ArrayVision software (GE Healthcare). For each three-by-three subarray, the local background determined in a surrounding square region was subtracted from each spot value. The average values for all spot pairs were then calculated and used for further calculations, except for those spot pairs differing by more than a factor of five. In these cases, the best single spot was visually determined and used. For the samples from mycelium grown in vitro, the values of the two fungal reference genes (actin and histone $\mathrm{H} 3$ ) were first normalized against the value from the glucose-grown culture, then averaged and used to normalize the values of the YSST unigenes. For the samples from corn leaves, the values for each plant reference gene (actin, histones $\mathrm{H} 2 \mathrm{~A}$ and $\mathrm{H} 4$, and ribosomal protein S11) were normalized against the noninoculated control. The normalized plant reference values for each infection timepoint were then averaged and used to normalize all spot values. Where applicable, background values from YSST unigenes in the uninfected control were subtracted from all samples of infected corn. Next, the values for the fungal reference genes were normalized against the value of the 0-hpi timepoint, averaged and used to normalize the values of the YSST unigenes. Finally, the values for each individual unigene were normalized against the lowest value in the infection time course.

\section{qRT-PCR.}

Primer pairs were initially tested in a temperature gradient on plant and fungal genomic DNAs and total RNAs to optimize the reaction conditions and assure the specificity of the reactions. qRT-PCR was performed using the iScript one-step RTPCR kit (Bio-Rad, München, Germany) in 20- $\mu$ l reactions containing $10 \mathrm{ng}$ of total RNA and $100 \mathrm{nM}$ each primer. For each 96-well plate, control reactions for the fungal references $\alpha$-actin and histone $\mathrm{H} 3$ were included in addition to the analyzed unigenes. Analyses were performed in triplicate using a MyiQ-single color real-time PCR detection system that was controlled by the iQ5 Standard Edition software (version 2.0; Bio-Rad). Reaction conditions were $10 \mathrm{~min}$ at $50^{\circ} \mathrm{C}$ for cDNA synthesis, $5 \mathrm{~min}$ at $95^{\circ} \mathrm{C}$ for inactivation of reverse transcriptase, followed by 50 cycles of $95^{\circ} \mathrm{C}$ for $5 \mathrm{~s}$ and $60^{\circ} \mathrm{C}$ for $40 \mathrm{~s}$ with data collection, and ended with a melt curve analysis of 1 min at $95^{\circ} \mathrm{C}, 1 \mathrm{~min}$ at $55^{\circ} \mathrm{C}$, and 81 cycles of $10 \mathrm{~s}$ at $55^{\circ} \mathrm{C}$ plus $0.5^{\circ} \mathrm{C} /$ cycle. Cycle threshold $(\mathrm{Ct})$ values were used as determined by the software. For each reaction, starting amounts of template were calculated to be $2^{-\mathrm{Ct}}$. Values from the no-template and noninoculated plant control reactions were subtracted from the values of the infection time course for each gene. For samples from in vitro cultures, only no-template control values were subtracted. qRT-PCR data were processed exactly as described for the macroarray hybridization data to allow direct comparison of the two data sets. Correction of the raw data for fungal biomass is essential to extract the real variation in transcript levels, resulting from regulatory mechanisms in the fungus. For each run, values for reference genes $\alpha$-actin and histone H3 were converted to relative values and averaged. Finally, values for each gene were normalized against the averaged reference values, and then expressed as relative fold value against the lowest value. This was performed separately for the infection time course and the in vitro samples. From the normalized relative values of the three repeats for each gene, mean and standard deviations were calculated.

\section{ACKNOWLEDGMENTS}

This work was supported by a DFG-grant (SFB 648, project A5). We thank A. Beutel, F. Weihmann, E. Vollmer, and I. Walde for skillful technical assistance; and O. K. Park (Kumho Life \& Environmental Science Laboratory, Kwangju, South Korea) for kindly providing pSMASH.

\section{LITERATURE CITED}

Ahn, N., Kim, S., Choi, W., Im, K. H., and Lee, Y. H. 2004. Extracellular matrix protein gene, EMP1, is required for appressorium formation and pathogenicity of the rice blast fungus, Magnaporthe grisea. Mol. Cells 17:166-173.

Akada, R., Murakane, T., and Nishizawa, Y. 2000. DNA extraction method for screening yeast clones by PCR. Biotechniques 28:668-670.

Alonso-Nunez, M. L., An, H. B., Martin-Cuadrado, A. B., Mehta, S., Petit, C., Sipiczki, M., del Rey, F., Gould, K. L., and de Aldana, C. R. V. 2005. Ace2p controls the expression of genes required for cell separation in Schizosaccharomyces pombe. Mol. Biol. Cell 16:2003-2017.

Ausubel, F. M., Brent, R., Kingston, R. E., Moore, D. D., Seidman, J. G., Smith, J. A., and Struhl, K., eds. 1994. Current Protocols in Molecular Biology, John Wiley \& Sons, Inc. New York.

Bell-Pedersen, D., Shinohara, M. L., Loros, J. J., and Dunlap, J. C. 1996 Circadian clock-controlled genes isolated from Neurospora crassa are late night- to early morning-specific. Proc. Natl. Acad. Sci. U.S.A. 93:13096-13101.

Bergstrom, G. C., and Nicholson, R. L. 1999. The biology of corn anthracnose-Knowledge to exploit for improved management. Plant Dis. 83:596-608.

Bouarab, K., Melton, R., Peart, J., Baulcombe, D., and Osbourn, A. 2002. A saponin-detoxifying enzyme mediates suppression of plant defences. Nature 418:889-892.

Carlile, A. J., Bindschedler, L. V., Bailey, A. M., Bowyer, P., Clarkson, J. M., and Cooper, R. M. 2000. Characterization of SNP1, a cell walldegrading trypsin, produced during infection by Stagonospora nodorum. Mol. Plant-Microbe Interact. 13:538-550.

Catanzariti, A. M., Dodds, P. N., and Ellis, J. G. 2007. Avirulence proteins from haustoria-forming pathogens. FEMS (Fed. Eur. Microbiol. Soc.) Microbiol. Lett. 269:181-188.

Chomczynski, P., and Sacchi, N. 1987. Single-step method of RNA isolation by acid guanidinium thiocyanate phenol chloroform extraction. Anal. Biochem. 162:156-159.

Coronado, J. E., Mneimneh, S., Epstein, S. L., Qiu, W. G., and Lipke, P. N. 2007. Conserved processes and lineage-specific proteins in fungal cell wall evolution. Eukaryot. Cell 6:2269-2277.

Cuomo, C. A., Gueldener, U., Xu, J. R., Trail, F., Turgeon, B. G., Di Pietro, A., Walton, J. D., Ma, L. J., Baker, S. E., Rep, M., Adam, G., Antoniw, J., Baldwin, T., Calvo, S., Chang, Y. L., DeCaprio, D., Gale, L. R., Gnerre, S., Goswami, R. S., Hammond-Kosack, K., Harris, L. J., Hilburn, K., Kennell, J. C., Kroken, S., Magnuson, J. K., Mannhaupt, G., Mauceli, E., Mewes, H.-W., Mitterbauer, R., Muehlbauer, G., Münsterkötter, M., Nelson, D., O’Donnell, K., Ouellet, T., Qi, W., Quesneville, H., Roncero, M. I. G., Seong, K.-Y., Tetko, I. V., Urban, M., Waalwijk, C., Ward, T. J., Yao, J., Birren, B. W., and Kistler H. C. 2007. The Fusarium graminearum genome reveals a link between localized polymorphism and pathogen specialization. Science 317:1400-1402.

Damveld, R. A., Arentshorst, M., VanKuyk, P. A., Klis, F. M., van den Hondel, C. A. M. J. J., and Ram, A. F. J. 2005. Characterisation of CwpA, a putative glycosylphosphatidylinositol-anchored cell wall man- 
noprotein in the filamentous fungus Aspergillus niger. Fungal Genet. Biol. 42:873-885.

Dean, R. A., Talbot, N. J., Ebbole, D. J., Farman, M. L., Mitchell, T. K., Orbach, M. J., Thon, M., Kulkarni, R., Xu, J. R., Pan, H. Q., Read, N. D., Lee, Y. H., Carbone, I., Brown, D., Oh, Y. Y., Donofrio, N., Jeong, J. S., Soanes, D. M., Djonovic, S., Kolomiets, E., Rehmeyer, C., Li, W., Harding, M., Kim, S., Lebrun, M.-H., Bohnert, H., Coughlan, S., Butler, J., Calvo, S., Ma, L.-J., Nicol, R., Purcell, S., Nusbaum, C., Galagan, J.E., and Birren, B. W. 2005. The genome sequence of the rice blast fungus Magnaporthe grisea. Nature 434:980-986.

El Gueddari, N. E., Rauchhaus, U., Moerschbacher, B. M., and Deising, H. B. 2002. Developmentally regulated conversion of surface-exposed chitin to chitosan in cell walls of plant pathogenic fungi. New Phytol. 156:103-112.

Gietz, R. D., and Woods, R. A. 2002. Transformation of yeast by lithium acetate/single-stranded carrier DNA/polyethylene glycol method. Guide to Yeast Genet. Mol. Cell Biol. Pt. B 350:87-96.

Goddard, N. J., Dunn, M. A., Zhang, L., White, A. J., Jack, P. L., and Hughes, M. A. 1993. Molecular analysis and spatial expression pattern of a low-temperature-specific barley gene, Blt101. Plant Mol. Biol. 23:871-879.

Goo, J. H., Ahn, Y., Park, O. K., and Park, W. J. 1999a. Selection of Drosophila genes encoding secreted and membrane proteins. Mol. Cells 9:564-568.

Goo, J. H., Park, A. R., Park, W. J., and Park, O. K. 1999b. Selection of Arabidopsis genes encoding secreted and plasma membrane proteins. Plant Mol. Biol. 41:415-423.

Hampton, R. Y., Gardner, R. G., and Rine, J. 1996. Role of 26S proteasome and HRD genes in the degradation of 3-hydroxy-3-methylglutaryl-CoA reductase, an integral endoplasmic reticulum membrane protein. Mol. Biol. Cell 7:2029-2044.

Hugot, K., Riviere, M. P., Moreilhon, C., Dayem, M. A., Cozzitorto, J., Arbiol, G., Barbry, P., Weiss, C., and Galiana, E. 2004. Coordinated regulation of genes for secretion in tobacco at late developmental stages: Association with resistance against oomycetes. Plant Physiol. 134:858-870

Hutchison, K. A., Green, J. R., Wharton, P. S., and O'Connell, R. J. 2002. Identification and localisation of glycoproteins in the extracellular matrices around germ-tubes and appressoria of Colletotrichum species. Mycol. Res. 106:729-736.

Hwang, C. S., and Kolattukudy, P. E. 1995. Isolation and characterization of genes expressed uniquely during appressorium formation by Colletotrichum gloeosporioides conidia induced by the host surface wax. Mol. Gen. Genet. 247:282-294

Jacobs, K. A., Collins-Racie, L. A., Colbert, M., Duckett, M., GoldenFleet, M., Kelleher, K., Kriz, R., LaVallie, E. R., Merberg, D., Spaulding, V., Stover, J., Williamson, M. J., and McCoy, J. M. 1997. A genetic selection for isolating cDNAs encoding secreted proteins. Gene 198:289-296.

Jacobs, K. A., Collins-Racie, L. A., Colbert, M., Duckett, M., Evans, C., Golden-Fleet, M., Kelleher, K., Kriz, R., La Vallie, E. R., Merberg, D., Spaulding, V., Stover, J., Williamson, M. J., and McCoy, J. M. 1999. A genetic selection for isolating cDNA clones that encode signal peptides. Methods Enzymol. 303:468-479.

Jones, J. D. G., and Dangl, J. L. 2006. The plant immune system. Nature 444:323-329

Kämper, J., Kahmann, R., Bolker, M., Ma, L. J., Brefort, T., Saville, B. J., Banuett, F., Kronstad, J. W., Gold, S. E., Muller, O., Perlin, M. H., Wosten, H. A. B., de Vries, R., Ruiz-Herrera, J., Reynaga-Pena, C. G., Snetselaar, K., McCann, M., Perez-Martin, J., Feldbrugge, M., Basse, C. W., Steinberg, G., Ibeas, J. I., Holloman, W., Guzman, P., Farman, M., Stajich, J. E., Sentandreu, R., González-Prieto, J. M., Kennell, J. C., Molina, L., Schirawski, J., Mendoza-Mendoza, A., Greilinger, D., Münch, K., Rössel, N., Scherer, M., Vraneš, M., Ladendorf, O., Vincon, V., Fuchs, U., Sandrock, B., Meng, S., Ho, E. C. H., Cahill, M. J., Boyce, K. J., Klose, J., Klosterman, S. J., Deelstra, H. J., OrtizCastellanos, L., Li, W., Sanchez-Alonso, P., Schreier, P. H., HäuserHahn, I., Vaupel, M., Koopmann, E., Friedrich, G., Voss, H., Schlüter, T., Margolis, J., Platt, D., Swimmer, C., Gnirke, A., Chen, F., Vysotskaia, V., Mannhaupt, G., Güldener, U., Münsterkötter, M., Haase, D. Oesterheld, M., Mewes, H.-W., Mauceli, E. W., DeCaprio, D., Wade, C. M., Butler, J., Young, S., Jaffe, D. B., Calvo, S., Nusbaum, C., Galagan, J., and Birren, B. W. 2006. Insights from the genome of the biotrophic fungal plant pathogen Ustilago maydis. Nature 444:97-101.

Kim, S., Ahn, I. P., Rho, H. S., and Lee, Y. H. 2005. MHP1, a Magnaporthe grisea hydrophobin gene, is required for fungal development and plant colonization. Mol. Microbiol. 57:1224-1237.

Klein, R. D., Gu, Q., Goddard, A., and Rosenthal, A. 1996. Selection for genes encoding secreted proteins and receptors. Proc. Natl. Acad. Sci. U.S.A. 93:7108-7113.
Lee, K. W., Kang, N. J., Heo, Y. S., Rogozin, E. A., Pugliese, A., Hwang, M. K., Bowden, G. T., Bode, A. M., Lee, H. J., and Dong, Z. 2008. Raf and MEK protein kinases are direct molecular targets for the chemopreventive effect of quercetin, a major flavonol in red wine. Cancer Res. 68:946-955.

Lee, S. J., Kelley, B. S., Damasceno, C. M. B., John, B. S., Kim, B. S., Kim, B. D., and Rose, J. K. C. 2006. A functional screen to characterize the secretomes of eukaryotic pathogens and their hosts in planta. Mol. Plant-Microbe Interact. 19:1368-1377.

Lee, Y. N., Kang, J. S., and Krauss, R. S. 2001. Identification of a role for the sialomucin CD164 in myogenic differentiation by signal sequence trapping in yeast. Mol. Cell Biol. 21:7696-7706.

Link, T. I., and Voegele, R. T. 2008. Secreted proteins of Uromyces fabae: Similarities and stage specificity. Mol. Plant Pathol. 9:59-66.

Martinez-Ruiz, A., Martinez del Pozo, A., Lacadena, J., Mancheno, J. M., Onaderra, M., and Gavilanes, J. G. 1997. Characterization of a natural larger form of the antifungal protein (AFP) from Aspergillus giganteus. Biochim. Biophys. Acta 1340:81-87.

Martinez, A. T., Speranza, M., Ruiz-Duenas, F. J., Ferreira, P., Camarero, S., Guillen, F., Martinez, M. J., Gutierrez, A., and del Rio, J. C. 2005. Biodegradation of lignocellulosics: Microbial chemical, and enzymatic aspects of the fungal attack of lignin. Int. Microbiol. 8:195-204.

Monteoliva, L., Matas, M. L., Gil, C., Nombela, C., and Pla, J. 2002. Large-scale identification of putative exported proteins in Candida albicans by genetic selection. Eukaryot. Cell 1:514-525.

Münch, S., Lingner, U., Floss, D. S., Ludwig, N., Sauer, N., and Deising, H. B. 2008. The hemibiotrophic lifestyle of Colletotrichum species. J. Plant Physiol. 165:41-51

Nombela, C., Gil, C., and Chaffin, W. L. 2006. Non-conventional protein secretion in yeast. Trends Microbiol. 14:15-21.

Olivieri, F., Zanetti, M. E., Oliva, C. R., Covarrubias, A. A., and Casalongue, C. A. 2002. Characterization of an extracellular serine protease of Fusarium eumartii and its action on pathogenesis related proteins. Eur. J. Plant Pathol. 108:63-72.

Paper, J. M., Scott-Craig, J. S., Adhikari, N. D., Cuomo, C. A., and Walton, J. D. 2007. Comparative proteomics of extracellular proteins in vitro and in planta from the pathogenic fungus Fusarium graminearum. Proteomics 7:3171-3183

Pazzagli, L., Cappugi, G., Manao, G., Camici, G., Santini, A., and Scala, A. 1999. Purification, characterization, and amino acid sequence of cerato-platanin, a new phytotoxic protein from Ceratocystis fimbriata $\mathrm{f}$. sp. platani. J. Biol. Chem. 274:24959-24964.

Perfect, S. E., Green, J. R., and O'Connell, R. J. 2001. Surface characteristics of necrotrophic secondary hyphae produced by the bean anthracnose fungus, Colletotrichum lindemuthianum. Eur. J. Plant Pathol. 107:813-819.

Phalip, V., Delalande, F., Carapito, C., Goubet, F., Hatsch, D., LeizeWagner, E., Dupree, P., Van Dorsselaer, A., and Jeltsch, J. M. 2005. Diversity of the exoproteome of Fusarium graminearum grown on plant cell wall. Curr. Genet. 48:366-379.

Schoffelmeer, E. A., Vossen, J. H., van Doorn, A. A., Cornelissen, B. J. and Haring, M. A. 2001. FEM1, a Fusarium oxysporum glycoprotein that is covalently linked to the cell wall matrix and is conserved in filamentous fungi. Mol. Genet. Genomics 265:143-152.

Schouten, A., Wagemakers, L., Stefanato, F. L., van der Kaaij, R. M., and van Kan, J. A. L. 2002. Resveratrol acts as a natural profungicide and induces self-intoxication by a specific laccase. Mol. Microbiol. 43:883894.

Shen, X., Belcher, A. M., Hansma, P. K., Stucky, G. D., and Morse, D. E. 1997. Molecular cloning and characterization of lustrin A, a matrix protein from shell and pearl nacre of Haliotis rufescens. J. Biol. Chem. 272:32472-32481.

Sposato, P., Ahn, J.-H., and Walton, J. D. 1995. Characterization and disruption of a gene in the maize pathogen Cochliobolus carbonum encoding a cellulase lacking a cellulose binding domain and hinge region. Mol. Plant-Microbe Interact. 8:602-609.

Sreenivasulu, N., Altschmied, L., Panitz, R., Hahnel, U., Michalek, W., Weschke, W., and Wobus, U. 2002. Identification of genes specifically expressed in maternal and filial tissues of barley caryopses: A cDNA array analysis. Mol. Genet. Genomics 266:758-767.

Thon, M. R., Nuckles, E. M., Takach, J. E., and Vaillancourt, L. J. 2002. CPR1: A gene encoding a putative signal peptidase that functions in pathogenicity of Colletotrichum graminicola to maize. Mol. PlantMicrobe Interact. 15:120-128.

Tyler, B. M., Tripathy, S., Zhang, X. M., Dehal, P., Jiang, R. H. Y., Aerts, A., Arredondo, F. D., Baxter, L., Bensasson, D., Beynon, J. L., Chapman, J., Damasceno, C. M. B., Dorrance, A. E., Dou, D. L., Dickerman, A. W., Dubchak, I. L., Garbelotto, M., Gijzen, M., Gordon, S. G., Govers, F., Grunwald, N. J., Huang, W., Ivors, K. L., Jones, R. W., Kamoun, S., Krampis, K., Lamour, K. H., Lee, M.-K., McDonald, W. H., Medina, M., Meijer, H. J. G., Nordberg, E. K., Maclean, D. J., Ospina-Giraldo, 
M. D., Morris, P. F., Phuntumart, V., Putnam, N. H., Rash, S., Rose, J. K. C., Sakihama, Y., Salamov, A. A., Savidor, A., Scheuring, C. F., Smith, B. M., Sobral, B. W. S., Terry, A., Torto-Alalibo, T. A., Win, J., Xu, Z., Zhang, H., Grigoriev, I. V., Rokhsar, D. S., and Boore J. L. 2006. Phytophthora genome sequences uncover evolutionary origins and mechanisms of pathogenesis. Science 313:1261-1266.

Wang, X., Allen, R., Ding, X., Goellner, M., Maier, T., de Boer, J. M., Baum, T. J., Hussey, R. S., and Davis, E. L. 2001. Signal peptide-selection of cDNA cloned directly from the esophageal gland cells of the soybean cyst nematode Heterodera glycines. Mol. Plant-Microbe Interact. 14:536-544.

Werner, S., Sugui, J. A., Steinberg, G., and Deising, H. B. 2007. A chitin synthase with a myosin-like motor domain is essential for hyphal growth, appressorium differentiation, and pathogenicity of the maize anthracnose fungus Colletotrichum graminicola. Mol. Plant-Microbe Interact. 20:1555-1567.

Yoshikawa, M., Ikegami, Y., Sano, K., Yoshida, H., Mitomo, H., Sawada, S., and Ishikawa, T. 2004. Transport of SN-38 by the wild type of hu- man $\mathrm{ABC}$ transporter $\mathrm{ABCG} 2$ and its inhibition by quercetin, a natural flavonoid. J. Exp. Ther. Oncol. 4:25-35.

You, B. J., and Chung, K. R. 2007. Phenotypic characterization of mutants of the citrus pathogen Colletotrichum acutatum defective in a $P a c C$-mediated $\mathrm{pH}$ regulatory pathway. FEMS (Fed. Eur. Microbiol. Soc.) Microbiol. Lett. 277:107-114.

Zierold, U., Scholz, U., and Schweizer, P. 2005. Transcriptome analysis of mlo-mediated resistance in the epidermis of barley. Mol. Plant Pathol. 6:139-151.

\section{AUTHOR-RECOMMENDED INTERNET RESOURCES}

NCBI Blast server: www.ncbi.nlm.nih.gov/blast

NCBI CDD database: www.ncbi.nlm.nih.gov/Structure/cdd/wrpsb.cgi SignalP 3.0, TMHMM, and SecretomeP 2.0 server: www.cbs.dtu.dk/services

Transporter Classification Database server: www.tcdb.org 